\title{
Odnawialne źródła energii - ochrona powietrza - ochrona klimatu
}

\section{Renewable Energy Sources - Air Protection - Climate Protection}

\section{Grzegorz Wiśniewski}

Instytutu Energetyki Odnawialnej

ORCID: https://orcid.org/0000-0001-7708-6058

E-mail: gwisniewski@ieo.pl

\section{Aneta Więcka}

Instytutu Energetyki Odnawialnej

ORCID: https://orcid.org/oooo-0002-6684-5845

E-mail: awiecka@ieo.pl

\section{Abstract}

Polish energy sector is moving away from the principles of sustainable development and this causes serious tensions within the European Union. Continuation of current trends may lead to ecological catastrophe. Europe and the world invest in zero-emission sources not only for ecological reasons. These sources, especially solar and wind energy subject to an inevitable decline in energy costs in the long term, and also mitigate risks related to fuel costs escalations and reduce costs of adjustments of coal fired plants to the environmental regulations. The authors of this article indicate that the efforts should be made towards rapid development of totally emission-free renewable energy sources and gradual displacement of combustion processes in the power industry. This transition cannot be implemented without seasonal heat storages and integration (market coupling) of heat and electricity markets.

Keywords - zero-emission sources, Polish energy sector, Renewable Energy Sources, climate protection, seasonal heat storages, integration of heat and electricity markets, market coupling 


\section{Wstęp}

Pomimo wysiłków kilku modernizacyjnie nastawionych ekip rządowych, w Polsce na przestrzeni ostatnich 30 lat nie nastąiła głębsza zmiana struktury paliwowej (tak jak to miało miejsce w krajach Zachodu), ani w sektorze elektroenergetyki, ani ciepłownictwa systemowego, ani transportu. Wręcz przeciwnie, pomimo całkowitego przeobrażania polskiej gospodarki z modelu socjalistycznego do gospodarki w stylu zachodnim, w energetyce nastapił stopniowy powrót do scentralizowanego modelu wytwarzania energii elektrycznej. Szeroko dostępne nowe technologie o charakterze przełomowych (inteligentne sieci, mikrosieci cieplne i elektryczne, małoskalowe instalacje odnawialnych źródeł energii, magazyny ciepła i energii elektrycznej) nie przyjęły się w polskiej energetyce.

Po okresie ożywionego zainteresowania odnawialnymi źródłami energii w pierwszej dekadzie XXI wieku, energetyka wraca do XX-wiecznego modelu, który zasadniczo realizowany był i jest w oparciu o procesy spalania na olbrzymią skalę, w tym spalania węgla (nowością w Polsce jest jego import na dużą skalę) i paliw płynnych (nieodmiennie importowanych) przez tradycyjne przedsiębiorstwa energetyczne. Towarzyszy temu wypychanie z rynku nowoczesnych i czystych technologii i tych którzy z nich chcieli korzystać: niezależnych wytwórców energii i tzw. prosumentów (gospodarstwa domowe, małe firmy i tzw. niezależnych producentów energii) w systemach generacji rozproszonej. Potwierdzenia wymaga teza, czy polska energetyka na długo utknęła w tradycyjnym modelu opartym na centralnej elektrowni na paliwa stałe jaki dominował w Europie i na świecie w latach 70. i 80. ubiegłego wieku, ale od którego na świecie powszechnie i coraz szybciej się odchodzi już od lat 90. zeszłego wieku.

Kontynuacja obecnych trendów może doprowadzić do katastrofy ekologicznej i gwałtowanego spowolnienia rozwoju kraju zarówno z przyczyn ekologicznych jak i ekonomicznych. Nie wiadomo, jak długo Polska będzie kontynuować obecnie, niezwykle ryzykowne ekologicznie i gospodarczo, obecne trendy. Opublikowany pod koniec listopada 2018 roku i długo oczekiwany projekt nowej (10 lat temu uzgodniono poprzedni dokument) strategii energetycznej - Politykea energetyczna Polski do 2040 roku (PEP 2040) [1] - nie napawa optymizmem, jeśli chodzi o przyśpieszenie zmian (a nawet sposobu myślenia), zwłaszcza w elektroenergetyce. Jest to kontynuacja trendów, jeśli chodzi 
o olbrzymią skalę zapotrzebowania na energię, powolne tempo zmian struktury paliwowej, jak i skutki ekologiczne.

W przeciwieństwie do rynku ciepła, gdzie działania na rzecz termomodernizacji i łagodniejsze zimy doprowadziły do zmniejszenia zużycia paliw, w elektroenergetyce (także w transporcie) nie zadziałały mechanizmy efektywności energetycznej. Rosnące zapotrzebowanie na energię elektryczną nie było kompensowane inwestycjami w źródła bezemisyjne, lub co najmniej niskoemisyjne. W efekcie konserwowania i modernizacji przestarzałej infrastruktury w polskiej energetyce od roku 2002 przestały spadać emisje $\mathrm{CO}_{2} \mathrm{i}$ innych zanieczyszczeń (zwłaszcza tych rakotwórczych, takich jak benzo(a)pireny). W przypadku $\mathrm{SO}_{2}$ i $\mathrm{NO}_{x}$ nastapiło znaczące obniżenie tempa ograniczania emisji. Energetyka odnawialna oparta - tak jak ma to miejsce w Polsce - na procesach spalania biomasy, w pewnym zakresie ogranicza emisje $\mathrm{CO}_{2}$, ale w przypadku benzo(a)pirenów, NOx, a zwłaszcza pyłów (PM10, PM2,5) wzmaga szkodliwe emisje. Dlatego wypełnianie kolejnych wymogów środowiskowych UE w tym zakresie staje się coraz większym wyzwaniem.

Różnica w „czystości ekologicznej” w energetyce pomiędzy Polską i Unią Europejską (UE) powiększa się zamiast pomniejszać, tak jak ma to miejsce w przypadku produktu krajowego brutto (PKB.) Można postawić tezę, że trendy emisji zanieczyszczeń do atmosfery stały się pochodna przyjętego zachowawczego modelu w energetyce, który od momentu wejścia Polski do UE charakteryzował się znacznie wolniejszym spadkiem wykorzystania węgla (faktycznie doszło do stabilizacji jego zużycia) i niższym niż w UE tempem wzrostu wykorzystania odnawialnych źródeł energii (OZE).

Nasuwa się teza, że Polska podczas 15-letniej obecności w Unii nie przeprowadziła zasadniczej modernizacji krajowej energetyki, a jedynie z opóźnieniem (czasami uzasadnionym zgodą UE - derogacjami) dostosowywała się do trendów i wymogów europejskich. Wbrew celom polityki unijnej nie zostały uruchomione skuteczne mechanizmy prawne niezbędne do trwałej innowacyjnej transformacji w kierunku proekologicznym. $\mathrm{Na}$ całym świecie rewolucja w energetyce polegająca na coraz szybszym odchodzeniu od paliw kopalnych na rzecz OZE trwa już od co najmniej dekady (od kilku lat także w takich krajach jak Chiny i Indie) i nie ma od niej odwrotu. Upada również model tradycyjnego przedsiębiorstwa (monopolu) energetycznego.

Światowa energetyka znalazła się w punkcie zwrotnym. Dotychczasowy wektor rozwoju zmienił kierunek, a krzywa po której poruszała się światowa energetyka osiagnęła 
swój punkt przegięcia. Chodzi zarówno o znaczący już udział OZE, zwłaszcza w elektroenergetyce, jak i o zatrzymanie w roku 2015 wzrostu globalnej emisji gazów cieplarnianych. Efekt skali nowych zjawisk jest znaczący. Nawet silnymi instrumentami prawnymi i politycznymi (stosowanymi obecnie w Polsce, w celu podtrzymania życia starego modelu) niezwykle trudno będzie o „recydywę”” światowego systemu w kierunku minionej już epoki. Wbrew dominującej krajowej retoryce, nic nie wskazuje, aby świat „zwariował" na punkcie ekologii i klimatu oraz innowacji, bo nowy system jest w efekcie tańszy od starego. W świetle trendów światowych trudno nie postawić tezy, że OZE to nie jest już „fanaberia naiwnych czy wybryki bogatych”. To konsekwentna polityka, którą wspiera twardy interes gospodarczy, który ma ku temu niezwykle silne argumenty ekonomiczne i społeczne. OZE stały się tzw. głównym nurtem (mainstreamem) nie tylko europejskiej, ale i światowej energetyki.

\section{Trendy rozwoju krajowej i unijnej energetyki ${ }^{1}$}

Polska energetyka jest zdominowana przez węgiel, którego wykorzystanie spada od początku transformacji (rok 1990), ale od połowy ubiegłej dekady (paradoksalnie, od momentu wejścia Polski do UE i przyjęciu przyjaznych dla środowiska przepisów unijnych) jest to spadek wolniejszy. W ostatnich latach zużycie węgla w polskiej gospodarce ustabilizowało się. Obecne trendy w zużyciu energii z węgla i z OZE stwarzaja iluzję, że węgiel w Polsce „na wieki wieków” pozostanie paliwem dominującym.

W Unii Europejskiej węgiel też był głównym paliwem dla energetyki (po ropie naftowej stosowanej głównie w transporcie) - do połowy lat 90. zeszłego wieku. W roku 1996 Unia zużyła po raz pierwszy więcej gazu ziemnego niż węgla. Obecnie poziom zużycia węgla w UE zbliżył się do poziomu zużycia energii jądrowej, która już od kilku lat notuje trend spadkowy. Wieloletnie trendy zużycia węgla i energii z OZE są zobrazowane na rysunku 1. Wynika z nich, że już w ciagu najbliższych kilku lat zużycie węgla w UE będzie mniejsze, niż zużycie energii z OZE. Energia z OZE stanie się drugim po gazie, źródłem energii do wytwarzania ciepła i energii elektrycznej. Będzie ona również zastępować paliwa nieodnawialne w transporcie.

\footnotetext{
${ }^{1}$ Informacje statystyczne podawane w tej części artykułu oparto na [2].
} 


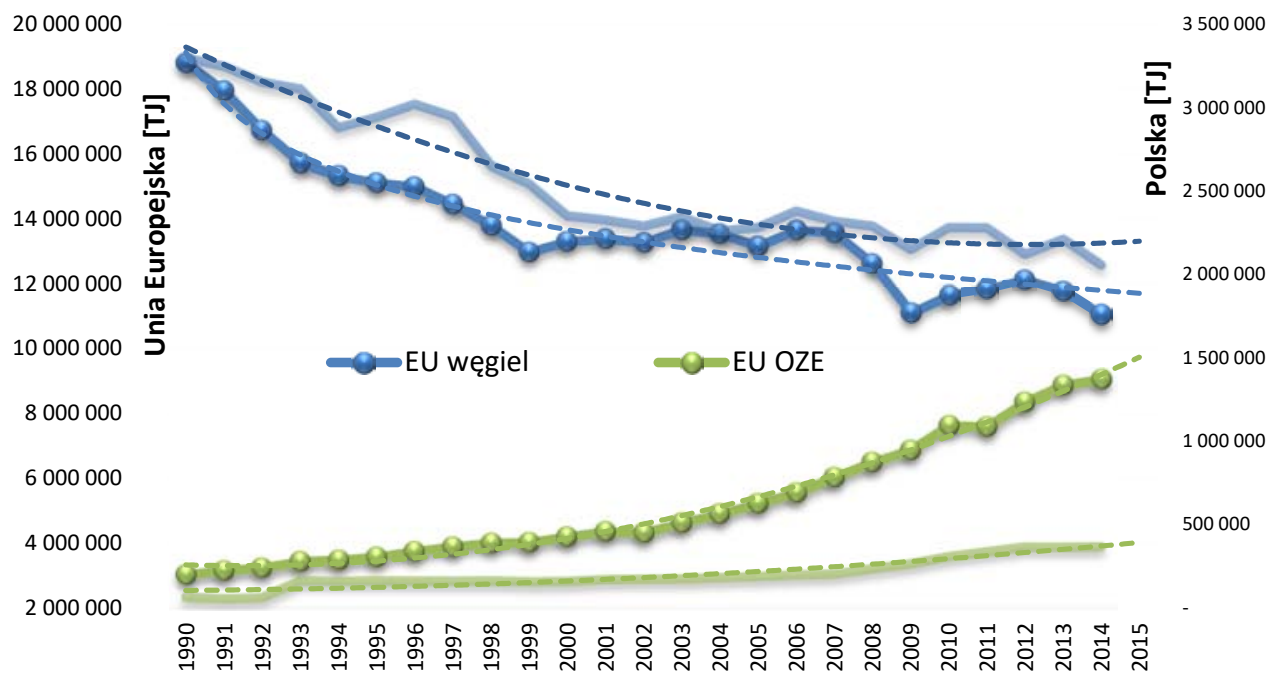

Rysunek 1. Porównanie zużycia wybranych paliw i energii brutto w Polsce i UE [T]]

Źródło: opracowanie własne na podstawie bazy danych Eurostat.

Nic nie wskazuje na to, aby unijne trendy zużycia paliw kopalnych i OZE mogły się odmienić. Wiele natomiast przemawia za tym, a w szczególności czynniki środowiskowe, że obecne nieśmiałe trendy odchodzenia od węgla na rzecz OZE w Polsce będą musiały się pogłębić.

Wykres obrazuje ryzyka związane nie tylko z „Europą dwóch prędkości” - jeśli chodzi o dekarbonizację - ale wręcz „dwóch kierunków” w przypadku odnawialnych źródeł energii. Pozostaje dylemat, czy uruchomione zostaną mechanizmy sprowadzające polską energetykę na tory rozwoju i innowacji i czy będzie to przejście ewolucyjne, czy też rewolucyjne (pod wpływem zbyt wysokich kosztów i niezadowolenia społecznego). Dotychczasowe zmiany były zbyt powolne, a zastany stan rzeczy nie odpowiada obecnym potrzebom cywilizacyjnym i aspiracjom coraz szerszych rzesz współczesnego społeczeństwa, świadomych zagrożeń środowiskowych.

Energetyka bazująca na węglu i procesach spalania w dalszym ciagu ma niezwykle duży wkład w emisje zanieczyszczeń do atmosfery i to nie tylko w przypadku $\mathrm{CO}_{2}$. Rysunek 2 pokazuje osłabienie trendu w Polsce w stosunku do UE w zakresie redukcji 
emisji $\mathrm{CO}_{2} \mathrm{z}$ pozyskiwania energii. Znamienne jest, że to osłabienie dobrego trendu nastapiło dokładnie wraz $\mathrm{z}$ wejściem w życie pakietu energetyczno-klimatycznego „3x20\%” w roku 2009.

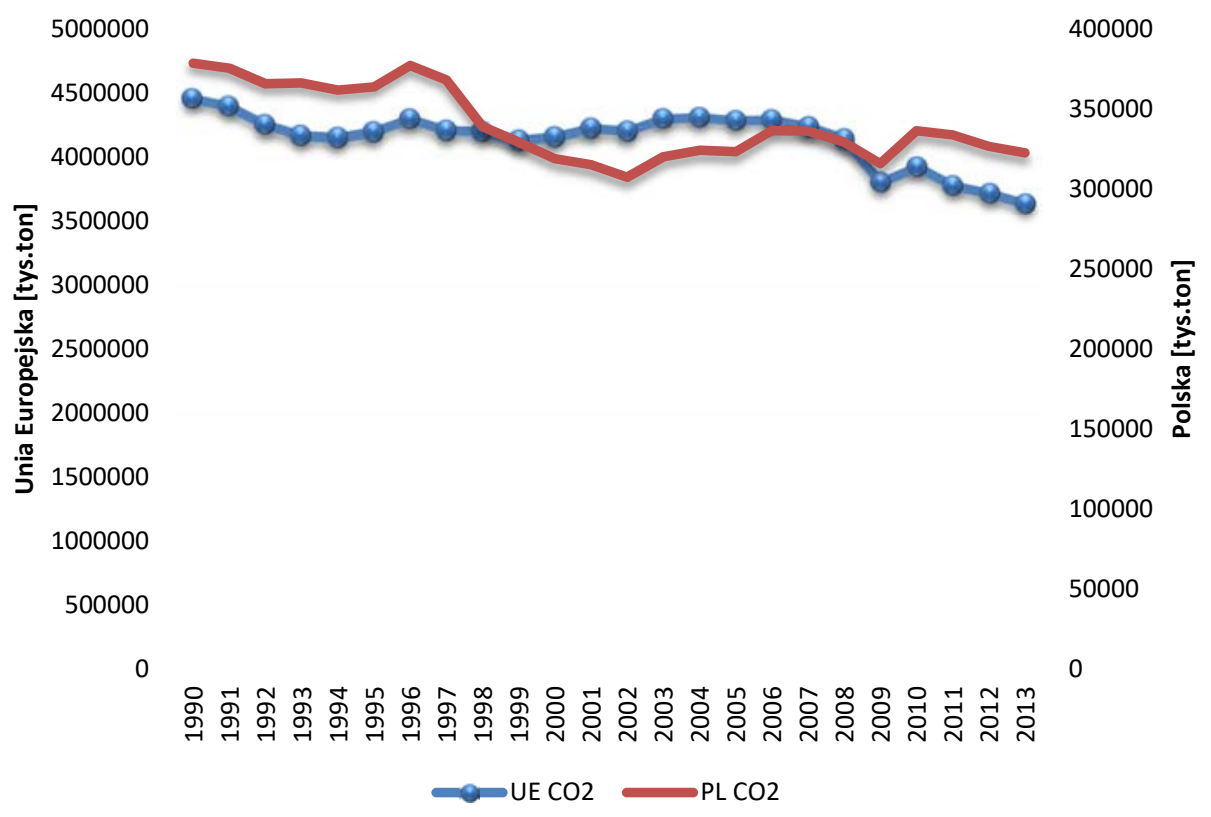

Rysunek 2. Historyczne emisje $\mathrm{CO}_{2}$ na terenie Polski i Unii Europejskiej

Źródło: opracowanie własne na podstawie danych Europejskiej Agencji Środowiska.

Polska przestała nadrabiać zaległości w stosunku do UE w ograniczeniu emisji tlenków siarki $\mathrm{SO}_{2}$, a od 2009 roku spowolniła tempo redukcji emisji tlenków azotu $\mathrm{NO}_{\mathrm{x}} \mathrm{w}$ porównaniu z ogółem UE. Ilustruje to rysunek 3.

Niekorzystne trendy ujawniają się również w przypadku innych zanieczyszczeń związanych ze spalaniem paliw kopalnych. W szczególności dotyczy to bezno(a)pirenów, pyłów oraz rtęci, które mogą wywołać bardzo poważne skutki zdrowotne. Ujawnione niekorzystne trendy dotyczące struktury zużycia paliw, małego udziału odnawialnych źródeł energii oraz szeroko rozumianej emisji wskazują na olbrzymią rolę energetyki odnawialnej w zakresie ochrony atmosfery. 


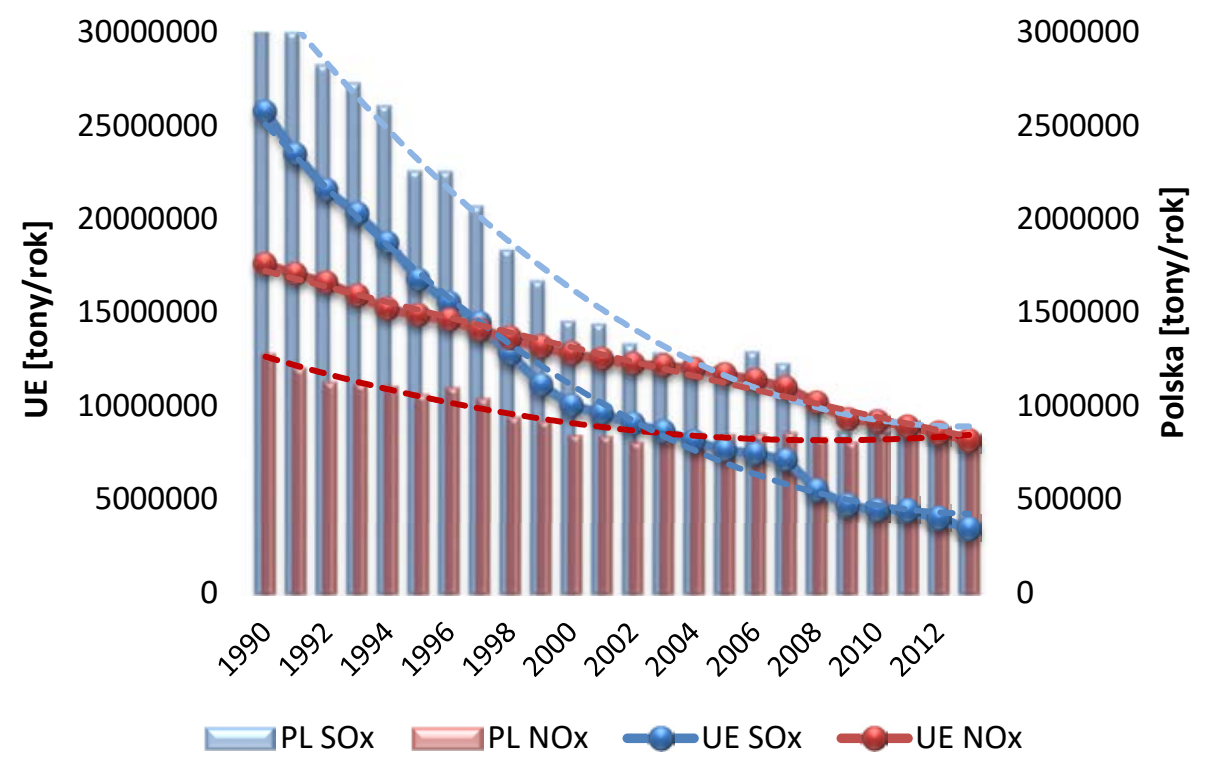

Rysunek 3. Porównanie historycznych emisji SOx i NOx na terenie Polski i Unii Europejskiej

Źródło: opracowanie własne na podstawie bazy danych Eurostat.

Stosunek społeczeństwa do energetyki, klimatu i OZE

Nawet jeżeli zmiany w systemie wytwarzania energii elektrycznej $\mathrm{i}$ jej dostarczania w ciagu ostatnich 30 lat były ewolucyjne i adaptacyjne i ostatecznie nie doprowadziły do zasadniczej zmiany w energetyce to jednak transformacja gospodarcza lat 90. poprzedniego wieku i pierwszych lat obecności Polski w UE (do końca pierwszej dekady obecnego stulecia) wiele zmieniła po stronie odbiorców energii, którzy w energetyce zaczęli cenić nie tylko wygodę, ale też efektywność i czystość ekologiczna. Dlatego trudno jest wytłumaczyć rozbieżność pomiędzy prowadzoną polityką energetyczną (której historyczne trendy przedstawiono powyżej), a oczekiwaniami Polaków.

Po pierwsze, badania potwierdzają że zdecydowana większość Polaków (78\%) uważa, że nasz kraj powinien wspierać Unię Europejską w prowadzeniu działań mających na celu ograniczenie emisji dwutlenku węgla [3]. Skąd zatem rozejście się kierunków transformacji energetyki i polityki klimatycznej w Polsce i w UE? Dane pokazuja, że preferowaną formą rozwoju energetyki dla Polaków pozostaje OZE, za którymi opowiada się aż $92,5 \%$ respondentów. $\mathrm{Na}$ tym tle o wiele niższe jest poparcie dla energetyki 
konwencjonalnej: węglowej (wspieranej przez 36,9\% respondentów) oraz opartej na gazie ziemnym i ropie naftowej, popieranej przez 51,4\% respondentów [3]. To też nie znajduje odbicia w prowadzonej polityce energetycznej.

Do podobnych wniosków prowadzą wyniki najnowszych badań CBOS (listopad 2018 roku). Aż 84\% respondentów dostrzega zagrożenia związane z ekologia - zmiany klimatyczne lub zanieczyszczenie środowiska. $72 \%$ ankietowanych wyraża poparcie dla odchodzenia od węgla (wzrost o 11 pkt. proc. od roku 2015), a tylko 19\% chce, by w ciagu 20-30 lat wytwarzanie energii opierać przede wszystkim na krajowych zasobach węgla kamiennego. Autorzy badania potwierdzają, że Polacy są coraz bardziej świadomi zagrożeń wynikających ze zmian klimatu. Zauważają też, że zmiany są wynikiem działalności człowieka (na działalność człowieka jako główna przyczynę zmian klimatu wskazało 75\% badanych [4)]. Przybywa zwolenników tezy, że zmiany klimatyczne to poważny problem $i$ trzeba im konkretnie przeciwdziałać. Trudno to pogodzić $z$ realizowana, bardzo zachowawcza polityką klimatyczną i systemowym organicznie tempa rozwoju energetyki odnawialnej. Badacze zadają sobie pytanie skąd swoista schizofrenia rozminięcie się oczekiwań społecznych i realizowanej polityki?

Dr Adrian Wójcik [Ibidem] stawia tezę, że deklarowanemu poparciu dla odnawialnych źródeł energii i stosunkowo niskiemu poparciu dla tradycyjnych form energetyki towarzyszy niechęć ponoszenia osobistych kosztów związanych z dofinansowaniem OZE. Jest to teza, która ma swoje uzasadnienie historyczne (wcześniej energia z odnawialnych źródeł była droższa od energii z węgla), ale obecnie nie ma ona oparcia w faktach. Rozwój OZE obniża koszty, a dalsze inwestycje w technologie spalania węgla podwyższają koszy koszty energii dla odbiorców. Potwierdzają to kolejne scenariusze kosztów energii elektrycznej opracowane przez Instytut Energetyki Odnawialnej [5; 6].

Profesor Paweł Ruszkowski wobec wyżej wskazanych przeciwstawnych trendów w wynikach badań opinii publicznej i faktów stawia tezę, że we wskazanych polach jest miejsce dla działań edukacyjno-informacyjnych. Jednak jego zdaniem, w sensie politycznym, kluczowe znaczenie ma wyraźny wzrost poparcia dla strategii odchodzenia od energetyki opartej na węglu. Ta zmiana w świadomości energetycznej Polaków towarzyszy polityce energetycznej realizowanej od roku 2015 przez rząd PiS i znajduje potwierdzenie w karbo-sceptycznej orientacji młodego pokolenia [7].

Autorzy niniejszego artykułu stawiają tezę, że decydujące znaczenie dla realizacji polityki energetycznej mało przyjaznej OZE i podszytej sceptycyzmem klimatycznym 
jest opinia wpływowej grupy zawodowej, jaka jest kadra kierownicza w branży paliwowo -energetycznej oraz rozwiązania instytucjonalne na szczeblu rządowym, w tym utworzenie na początku roku 2016 Ministerstwa Energii, które stało się regulatorem, a właściwie i reprezentantem interesów branży paliwo-energetycznej, a nie konsumentów energii czy innych grup społecznych [8]. W pewnym sensie tezę tę potwierdzają wcześniejsze badania świadomości kadry kierowniczej w elektroenergetyce, autorstwa prof. Ruszkowskiego z roku 2009 (wywiady i badania focusowe), z których wynikało, że środowiska te mają silnie konserwatywny światopogląd, zorientowany na wartości wspólnotowe i etatystyczne [9].

\section{Strategia energetyczna: zapowiedź przełomu czy kontynuacja?}

Brak aktualizacji zasadniczych dokumentów strategicznych i programowych dotyczycących energetyki był jedną z najczęściej głoszonych tez o przyczynach realizacji przez kompleks paliwowo-energetycznej zachowawczych scenariuszy w zakresie ochrony klimatu i wdrażania OZE. Ostatnia Polityka energetyczna Polski do 2030 roku została przyjęta przez rząd w roku 2009 i nie była aktualizowana (choć wymogi prawne nakazywały, aby tak się stało już w roku 2012), a Krajowy plan działan w zakeresie odnawialnych źródeł energï nie był aktualizowany od roku 2010 (choć już kilka lat temu stał się nieaktualny).

Efekty realizacji nieaktualnych dokumentów są widoczne. Najnowszy (listopad 2018) raport GUS Energia ze źródeł odnawialnych w 2017 r. [10] potwierdza tylko stagnacje, a nawet regres w latach 2016-2017 w sektorze odnawialnych źródeł energii, który realnie grozi niewypełnieniem przez Polskę zobowiązań międzynarodowych wynikających z unijnej dyrektywy o promocji energii z OZE (minimum 15\% udziału energii z OZE) [11] - rysunek 4.

Znając długości cykli inwestycyjnych dla odnawialnych źródeł energii nietrudno zauważyć, że w roku 2020 może zabraknać niemal 4\% energii z tych źródeł. Potwierdza to raport Najwyższej Izby Kontroli Rozwój sektora odnawialnych źródeł energii [12]. Według kontrolerów osiagnięcie przez Polskę założonego celu 15\% udziału energii z OZE w roku 2020 może być zagrożone (w roku 2016 wskaźnik przekroczył tylko 11\% i był najniższy od roku 2013). W konsekwencji Polska prawdopodobnie stanie przed koniecznością dokonania statystycznego transferu energii z OZE z państw członkowskich, które mają nadwyżkę tej energii. Koszty tego transferu mogą wynieść nawet 
8 mld zł i pojawią się po stronie budżetu państwa najpóźniej w roku 2020. Powyższe zagrożenia nie spotkały się jak dotychczas z propozycją działań, które mogłyby ograniczyć skalę ryzyka i następstw niespełnienia celu lub ograniczyć koszty.

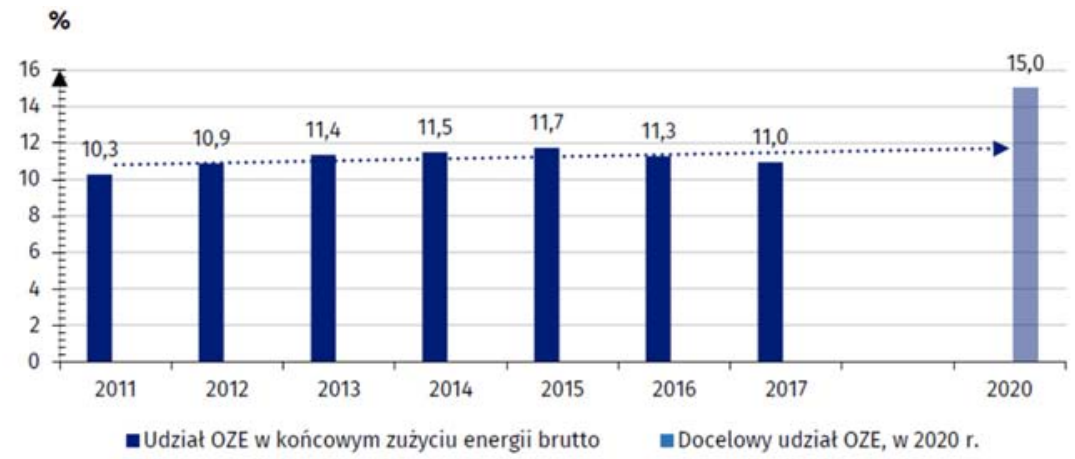

Rysunek 4. Udział energii ze źródeł odnawialnych w końcowym zużyciu energii brutto wraz z trendem do celu (krajowego zobowiązania) w roku 2020

Źródło: [10, s. 2].

W opublikowanym 22 listopada 2018 roku przez Ministerstwo Energii projekcie Polityki energetycznej Polski do 2040 roku [1] nie ma żadnych działań, które miałyby wesprzeć realizacje celu OZE na 2020 roku, ani też planu realizacji rozwoju tej gałęzi energetyki, zgodnie z nowymi celami UE na 2030 rok (32\% energii z OZE), zgodnie z nową dyrektywą o promocji OZE (tzw. RED II) [13] oraz „Pakietem zimowym” jedenastu nowych unijnych dyrektyw i rozporządzeń klimatyczno-energetycznych z grudnia 2016 roku (już uzgodnionych), które wyznaczają także cele na 2030 rok dla efektywności energetycznej (spadek zużycia energii i 32,5\% w stosunku do 2005 roku) i redukcji emisji $\mathrm{CO}_{2}$ (o 43\% w sektorze ETS) [14].

Niestety, projekt Polityki energetycznej Polski do 2040 roku wytycza znacznie niższe cele dla Polski. Ministerstwo Energii proponuje na rok 2030: udziały energii z OZE 21\% (zamiast średnich dla UE - 32\%), redukcję emisji $\mathrm{CO}_{2}$ o $30 \%$ (zamiast 43\%) [1], przy czym redukcja została obliczana w stosunku do roku 1990, co w praktyce, w stosunku do właściwego roku bazowego w roku 2005, może oznaczać jej wzrost). Jeżeli te plany zostaną zrealizowane, krajowa polityka energetyczna i klimatyczna pójdzie jeszcze bardziej w odmiennym kierunku, niż polityka Wspólnoty, z wszelkimi konsekwencjami. 
Choć dokument Ministerstwa Energii skupia się na najbardziej innowacyjnej elektroenergetyce, to proponuje odejście od dalszego rozwoju lądowych farm wiatrowych (w roku 2017 wyprodukowały 15 TWh), a w ich miejsce proponuje wprowadzenie m.in. elektrociepłowni na węgiel kamienny czy (w dalszej kolejności, ok. roku 2030) morskich farm wiatrowych. W efekcie nawet w przypadku energii elektrycznej z OZE, która w UE w roku 2030 będzie miała udziały ok. 51\% (obecnie 43\%) [15], Polska realizując powyższy plan (rysunek 5) jeszcze bardziej odchyliłaby się od trendów unijnych i naraziłaby się na wysokie koszty paliw (koszty krajowego węgla będą rosły, podobnie jak import) i rosnace koszty uprawnień do emisji $\mathrm{CO}_{2}$, co będzie musiało się przełożyć na dalszy wzrost cen energii elektrycznej.

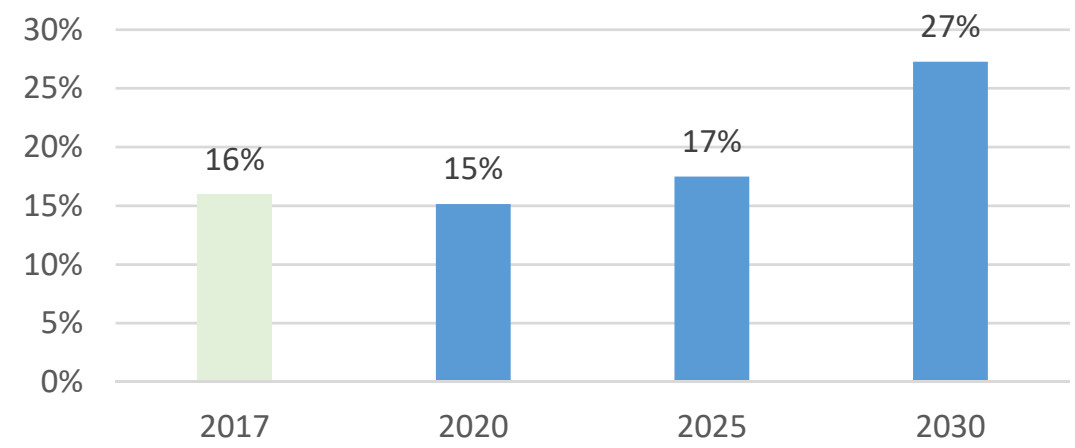

Rysunek 5. Procentowy udział energii elektrycznej z OZE w produkcji energii elektrycznej w Polsce Źródło: opracowanie własne na podstawie $[1 ; 18]$.

PEP 2040 może mieć, niestety, charakter samosprawdzającej się przepowiedni, petryfikującej status quo wbrew interesowi ogółu społeczeństwa i gospodarki. A skoro jest tak konsekwentnie forsowana, to oznacza, że z pewnością leży w interesie grupy jej apologetów, skupionych wokół ośrodka władzy dysponującego narzędziami kształtowania prawa.

W jakim kierunku powinna rozwijać się polska energetyka? Całkowicie bezemisyjna elektroenergetyka

Kontynuacja obecnych trendów może doprowadzić do katastrofy ekologicznej i gwałtowanego spowolnienia rozwoju kraju, zarówno z przyczyn ekologicznych, 
jak i ekonomicznych. Europa i świat inwestują w źródła bezemisyjne nie tylko z powodów ekologicznych. Kraje i inwestorzy inwestują w OZE przede wszystkim dlatego, że te źródła po zainstalowaniu prowadzą do nieuchronnego spadku kosztów energii w dłuższym okresie i dzięki odnawialnym źródłom energii poprawiają konkurencyjność, ale uwzględniają też ryzyka po stronie kosztów paliw i rosnących wymagań i kosztów ochrony środowiska.

Wybieraja przede wszystkim technologie OZE niewykorzystujące technologii spalania, stąd powolne odchodzenie od biomasy i biopłynów, traktowanych dotychczas jako odnawialne źródła ze świadomością ryzyka niezrównoważności wykorzystania zasobów biomasy (nieoczywisty cykl $\mathrm{CO}_{2}$ ) oraz wysokiej emisji innych zanieczyszczeń z procesów spalania (negatywny wpływ na jakość powietrza i powstawanie smogu). Dlatego Unia w swojej strategii rozwoju OZE i przepisach z zakresu ich promocji (dyrektywa RED II [13]) wycofała się ze wspierania upraw energetycznych i wprowadza stopniowe ograniczenia na energetyczne wykorzystanie biomasy leśnej (na początek w większych źródłach spalania biomasy). Całkowite odchodzenia od procesów spalania paliw, także w energetyce odnawialnej, jest już trendem ogólnoświatowym.

Naukowcy z Uniwersytetu Stanforda przygotowali globalne analizy, w których uwzględniono także Polskę, a w których badano możliwości pokrycia wszystkich, w tym także cieplnych i transportowych potrzeb energetycznych, energia z tzw. WWS (wind, water and sunlight) bezemisyjnych źródeł wiatrowych i słonecznych z niewielkim udziałem energii wodnej i geotermalnej [16].

W analizie tej zostały wykluczone technologie spalania paliw i zastapione bezemisyjnymi. Uczeni wykazali, że byłoby to możliwe już w roku 2050 i przyniosłoby 94 tys. miejsc pracy do obsługi „,nowej energetyki” oraz 110 tys. przy wytwarzaniu urządzeń i ich instalacji. Największy wkład w energetykę wniosłyby lądowa i morska energetyka wiatrowa (odpowiednio 43\% i 23\%) oraz energetyka słoneczna fotowoltaiczna, w tym farmy słoneczne (12\%), słoneczna energetyka przemysłowa (10\%) i fotowoltaika na domach mieszkalnych (5\%) - rysunek 6.

Odejście od procesów spalania paliw (czyli zmagazynowanej w nich przez miliony lat energii słonecznej) wymaga przemyślnej integracji bezemisyjnych odnawialnych źródeł energii z efektywnymi, tanimi, czystymi ekologicznie i trwałymi magazynami energii. Naukowcy twierdza, że nie mogą to być najsilniej obecnie promowane akumulatory litowo-jonowe, ale podziemne, wielowymiarowe magazyny termalne (tzw. UTES - ang. 
Underground Thermal Energy Storage), które w porównaniu do innych mają o rząd wielkości niższe nakłady kapitałowe i znacznie dłuższe zdolności magazynowania energii [17]. Rozwój OZE pozwala zatem nie tylko na zwiększenie skuteczności ochrony powietrza, w tym eliminację niskiej emisji, ale także na przykład na ochronę wód przed oddziaływaniem energetyki węglowej.

\section{$100 \%$ POLSKA}

Transformacja polskiej gospodarki energetycznej w kierunku $100 \%$ wykorzystania Odnawialnych Źródeł Energii we wszystkich jej sektorach (energetyka zawodowa, transport, przemyst)

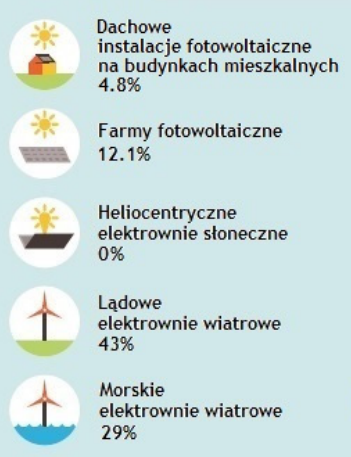

STABILNY RYNEK PRACY Liczba stanowisk, które zapewnią zatrudnienie w perspektywie 40 lat
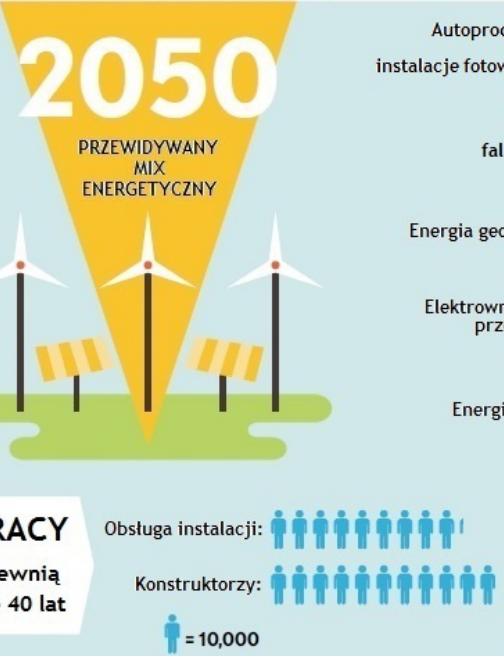

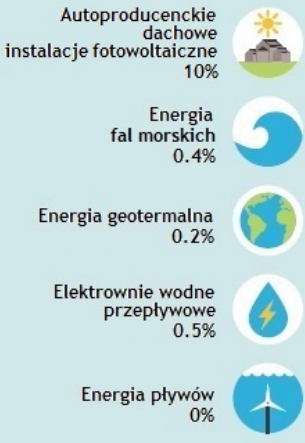

94,001 110,060

Rysunek 6. Scenariusz pokrycia wszystkich polskich potrzeb energetycznych w 2050 roku przez źródła nieemisyjne, elektryczne

Źródło: [16], oprac. graficzne własne.

Uniwersytet Stanforda w swoim symulacjach dla Polski także zakłada pełną elektryfikację transportu i ciepłownictwa oraz stosunkowo szybkie odejście od procesów spalania. Największym wyzwaniem wydaje się transformacja ciepłownictwa, w tym przede wszystkim systemowego, w którym udział OZE jest dotychczas najmniejszy. Zdaniem 
autorów, ciepłownictwo z uwagi na bardziej rozproszoną strukturę własnościową i możliwość działań lokalnych ma szanse na przyspieszoną transformację i na znaczące obniżenie nie tylko emisji $\mathrm{CO}_{2}$, ale także lokalnych zanieczyszczeń wywołujących smog.

\section{Ciepłownictwo w Polsce - jak dokonać przejścia ze spalania węgla do OZE?}

W polskiej energetyce oprócz produkcji energii elektrycznej ważną rolę odgrywa produkcja ciepła, która w opiera się zasadniczo na paliwach kopalnych. Obecnie jednostki wytwórcze zasilające systemy ciepłownicze (korzysta z nich 40\% odbiorców ciepła) w zdecydowanej większości wykorzystuja paliwa kopalne, przy czym udział węgla kamiennego wynosi aż 74\%. Odnawialne źródła energii w tzw. ciepłownictwie systemowym stanowią ciagle mały fragment struktury paliwowej - niewiele więcej niż 3\% (dane Urzędu Regulacji Energetyki za rok 2016 [18]). Systemy ciepłownicze maja przed sobą do zagospodarowania olbrzymi i jeszcze mało wykorzystany potencjał odnawialnych zasobów energii oraz mogą wnieść znaczący wkład w realizację polskich zobowiązań w zakresie udziałów energii z OZE do końca roku 2020.

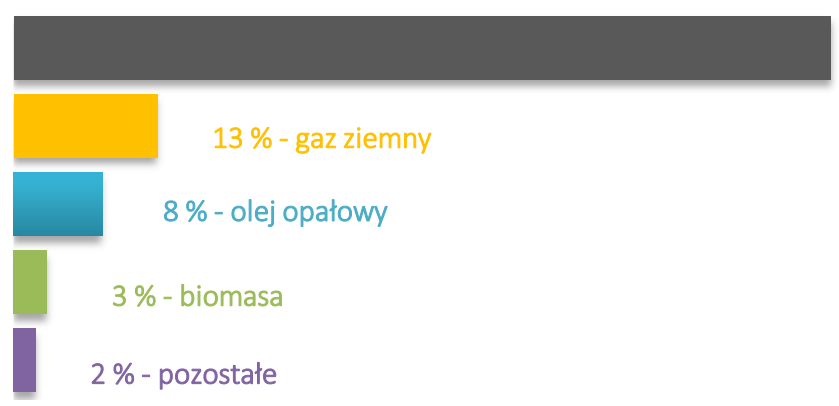

Rysunek 7. Struktura paliw wykorzystywanych w polskich systemach ciepłowniczych

Źródło: opracowanie własne na podstawie [19].

Wzrost wykorzystania odnawialnych źródeł energii w systemach ciepłowniczych, początkowo zaniedbywany, staje się jednym z priorytetów Unii Europejskiej w promocji ogólnego wzrostu udziałów OZE w zużyciu energii oraz w działaniach na rzecz zwalczania emisji zanieczyszczeń (smogu) i przeciwdziałaniu zmianom klimatu. Polski cel na 
udziały OZE w roku 2020 został określony na 15\%, ale przyjęty w 2010 roku Krajowy plan dz̧iałań w zakresie energii ze źródeł odnawialnych zakłada realizację tego celu o ile udział energii z OZE w samym ciepłownictwie w 2020 roku osiagnie 17,1\% [19].

Nie są to jedyne zobowiązania unijne, które dotyczą ciepłownictwa. Dyrektywa o efektywności energetycznej [20] stawia wymóg osiagania m.in. dzięki OZE lub wykorzystaniu ciepła odpadowego (w obu przypadkach potrzebne sa magazyny ciepła), statusu efektywnego systemu ciepłowniczego. Jednym z rekomendowanych sposobów osiagania statusu efektywnego systemu ciepłowniczego jest budowa w systemie ciepłowniczych różnych OZE (w tym kolektory słoneczne, wykorzystanie taniej energii z elektrowni wiatrowych, kotłów na biomasę, wykorzystanie energii geotermalnej i pomp ciepła), które w sumie, też dzięki magazynom ciepła, zapewnią minimum 50\% udział w strukturze wytwarzania ciepła. Obecnie, według Izby Gospodarczej Ciepłownictwo Polskie, aż 83\% przedsiębiorstw ciepłowniczych nie spełnia wymogów efektywnego systemu ciepłowniczego [21].

Ponadto dyrektywa „MCP” w sprawie ograniczania emisji niektórych zanieczyszczeń do powietrza ze średnich obiektów energetycznego spalania wymaga spełnienia - m.in. dzięki wprowadzaniu OZE i magazynów ciepła (w miejsce najbardziej emisyjnych kotłów węglowych) - coraz ostrzejszych standardów emisyjnych dotyczących dwutlenku siarki $\left(\mathrm{SO}_{2}\right)$, tlenków azotu (NOx) i cząstek stałych (pyłów) [22]. Stopniowe zastępowanie przez źródła odnawialne najstarszych kotłów na paliwa stałe pozwali na uniknięcie w przedsiębiorstwach ciepłowniczych kosztowych nakładów na ich modernizację i dostosowanie do nowych standardów środowiskowych.

Komisja Europejska w ramach komunikatu w sprawie „Strategia UE w zakresie ogrzewania i chłodzenia”, apeluje o całkowite odejścia od wykorzystania paliw stałych w ciepłownictwie do roku 2040 i całkowitego wyeliminowania paliw kopalnych w ciepłownictwie do roku 2050, przy jednoczesnym wzroście udziałów ciepła z OZE w UE z 16,5\% w roku 2013 do ok. 50\% w roku 2050 i wykorzystaniu ciepła odpadowego [23].

Polityka unijna przekłada się na kolejne zobowiązania - na rok 2030. Nowa dyrektywa (RED II) w sprawie promowania stosowania energii z OZE [13] mówi o obowiązku osiagnięcia rocznego wzrostu o co najmniej 1\%, udziału OZE w systemach ciepłowniczych.

Najbliższe kilka, kilkanaście lat w polskim ciepłownictwie będzie okresem przyśpieszonych przemian technologicznych i transformacji systemów ciepłowniczych 
w kierunku efektywnych energetycznie i niskoemisyjnych, z coraz większym udziałem energii ze źródeł odnawialnych. Dyrektywa o promocji OZE z roku 2009 wymaga - w całym okresie do 2020 roku - wzrostu udziałów OZE we wszystkich sektorach zapotrzebowania na energię, także w ciepłownictwie (wcześniejsza dyrektywa dotyczyła tylko promocji energii elektrycznej) [11]. Przedsiębiorstwa ciepłownicze w Polsce powoli, poczynając od lat 90. ubiegłego wieku, zaczęły stosować OZE. Najpierw ciepłownie zaczęły wykorzystać biomasę, potem podjęły próby z wykorzystaniem energii geotermalnej. Dopiero od roku 2010 zaczęły powstawać instalacje wykorzystujące energię promieniowania słonecznego, początkowo w niewielkiej skali.

Polska jest jednym z wiodących krajów europejskich pod względem ciepła systemowego i już tylko ten fakt wskazuje na olbrzymi potencjał także dla OZE w tym zakresie, zarówno w koncesjonowanych przedsiębiorstwach ciepłowniczych, spółdzielniach i wspólnotach mieszkaniowych, jak i na osiedlach deweloperskich. W celu szerokiego wykorzystania źródeł odnawialnych w ciepłownictwie należy pokonać pewne ograniczenia natury technicznej. Obecnie stosowane technologie w ciepłownictwie systemowym, oparte na spalaniu paliw stałych i starych modelach biznesowych, które zakładaja utrzymanie zapotrzebowania na ciepło na dotychczasowym poziomie przy stosunkowo wysokiej temperaturze jego odbioru, uniemożliwiaja znaczące zwiększenie udziału OZE (ponad kilka procent), bez natrafienia na bariery. Jedną z barier są ograniczone zasoby biomasy i rosnące koszty (wraz ze wzrostem zapotrzebowania), która jako jedyne źródło OZE może dostarczać ciepło o wysokiej temperaturze.

Instytut Energetyki Odnawialnej, przyjmując założenie, że (pod wpływem regulacji unijnych) wszystkie koncesjonowane przedsiębiorstwa ciepłownicze będą dążyć do uzyskiwania statusu efektywnego systemu ciepłowniczego oraz uwzględniając trend do wprowadzania nowych technologii ciepłowniczych (zaliczanych do III i IV generacjita ostatnia obejmuje technologie, które nie bazują za procesach spalania), dokonał oceny realnego potencjału inwestycyjnego w OZE w ciepłownictwie. W tym celu wykorzystano tzw. scenariusz Energy Revolution, który bazuje na symulacjach modelem MESAP całego krajowego miksu energetycznego do roku 2050, w którym w bilansie do roku 2030 (perspektywa inwestorska) wyodrębniono subscenariusz ciepła systemowego. Uzyskano wyniki, które w pełni potwierdziły możliwość uzyskania w koncesjonowanych przedsiębiorstwach ciepłowniczych $10 \mathrm{GW}$ mocy OZE do 2030 roku, w tym 4,2 GW nowych mocy ze źródeł całkowicie bezemisyjnych: kolektory słoneczne (3 MG), energia 
elektryczna (niezbilansowana) z efektowni wiatrowych (niemal 0,5M GW) oraz geotermia $(0,8$ GW) [24].

Wyniki obliczeń kosztów ciepła (tzw. LCOE) dla takich inwestycji, rozłożone na cały okres 20 lat, wynosiły średnio (dla różnych wariantów z sezonowymi magazynami ciepła i możliwe najmniejszym udziałem kotłów na biomasę pełniących jedynie rolę szczytowych w celu ciagłego „zabezpieczenia” dostaw ciepła o określonej temperaturze czynnika na wejściu w instalacjach pilotażowych) ok. 52 zł/GJ i były nieco wyższe od średniej ceny ciepła z systemów ciepłowniczych w roku 2016. Jeżeli jednak uwzględnić trendy wzrostu cen ciepła w przedsiębiorstwach koncesjonowanych (dane URE), a tym bardziej wymagane nakłady na dostosowanie się ciepłowni do dyrektywy „MCP” i rosnące koszty uprawnień do emisji $\mathrm{CO}_{2}$, to w latach 2019-2022 nastąpi zrównanie się cen ciepła z obecnych źródeł wytwarzania z cenami ciepła z systemów zmodernizowanych dzięki OZE (umożlwiającymi obniżenie udziałów węgla w wytwarzania ciepła ze 100\% do $50 \%)$.

Wyniki analiz pokazują, że przy kończących się, przyznanych w roku 2009, derogacjach na ograniczanie emisji $\mathrm{CO}_{2}$ (zgodnie ze ścieżką dla całej UE) i wzroście kosztów uprawnień do emisji (zgodnie z nową ścieżką w znowelizowanej w roku 2018 dyrektywie ETS [25]), odchodzenia od węgla (dekarbonizacja) w polskim ciepłownictwie prowadzi do szybkiego obniżenia kosztów ciepła dla odbiorców.

Wpływ odnawialnych źródeł energii na obniżenie kosztów ciepła (nowe zjawisko) i dążenie do minimalizacji obciążeń dla odbiorców ciepła są szczególnie ważne dla przedsiębiorstw ciepłowniczych będących w gestii miast (większość z obecnych przedsiębiorstw), które odpowiadają bezpośrednio za koszty usług dla mieszkańców. To między innymi dlatego potencjał i możliwości szerokiego wykorzystania OZE w ciepłownictwie znajduja potwierdzenie w oczekiwaniach branży ciepłowniczej.

Diagnozę możliwości w tym zakresie przyniosły wyniki ankiety przeprowadzonej przez IEO, we współpracy z Izbą Gospodarczą Ciepłownictwo Polskie, w lutym 2018 roku wśród przedsiębiorstw ciepłowniczych. W ankiecie wzięły udział 44 podmioty operujące 49 systemami ciepłowniczymi (13,7\% w łącznej mocy zainstalowanej w polskich systemach ciepłowniczych). Wyniki ankiety potwierdziły duże zainteresowanie przedsiębiorstw ciepłowniczych budową magazynów ciepła i wykorzystaniem różnych rodzajów OZE, także dotychczas wykorzystanych w małym lub znikomym zakresie, jak energia słoneczna termiczna, czy wiatrowa (elektroogrzewnictwo). Stosunkowo 
największym zainteresowaniem ankietowanych przedsiębiorstw cieszą się kotły na paliwa z biomasy. Wiazże się to z tym, że kotły biomasowe mogą stanowić źródło stabilizujące moce ciepłownicze i są bezpośrednim zamiennikiem dla kotłów węglowych. Duże zainteresowanie magazynami ciepła oraz kolektorami słonecznymi to już wyraźnie dostrzegalna, postępująca zmiana w podejściu do OZE i ich miejsca w systemach ciepłowniczych.

W celu uruchomienia innowacyjnego potencjału modernizacyjnego w ciepłownictwie i dokonania skoku technologicznego dzięki OZE, niezbędny wydaje się szeroko pomyślany program wsparcia dla ciepłownictwa. Narodowy Fundusz Ochrony Środowiska i Gospodarki Wodnej rozpoczął prace nad pilotażowym programem, który będzie wspierał wdrażanie w ciepłownictwie innowacyjnych i inteligentnych technik, OZE i magazynów ciepła [27].

\section{Podsumowanie}

Analiza trendów wskazuje na to, że Polska stopniowo odchodzi od zasad zrównoważonego rozwoju, a to wywołuje poważne napięcia wewnątrz Unii Europejskiej, też z powodu zbyt wolnego rozwoju odnawialnych źródeł energii. Świadomość rozejścia się istoty biznesu państwowych koncernów energetycznych z głębszymi podstawami zrównoważonego rozwoju zielonej teologii odziera politykę energetyczną ze złudzeń natury etycznej i religijnej oraz zmusza do zadania pytania o sens pracy i odpowiedzialność za ochronę atmosfery i klimatu. Pozorowane działania z obszaru społecznej odpowiedzialności biznesu i granie na strunach rzekomego patriotyzmu gospodarczego nie wystarczą. Niedomowienia, a nawet kłamstwa klimatyczne i ekonomiczne, też nie.

Nie można również zapominać, że Polska aspiruje do pierwszej 20. krajów pod względem PKB i pierwszej 40. krajów pod względem PKB na głowę mieszkańca, jest najczęstszym (po Niemcach) organizatorem światowych konferencji klimatycznych (COP) i członkiem UE. Nasz kraj nie może już uciekać od odpowiedzialności na arenie międzynarodowej, motywując to biedą i koniecznością rozwoju gospodarczego, a pomijać zdrowie wszystkich obywateli i konkurencyjność gospodarki, a zwłaszcza sektora MŚP (obecnie największą i pierwszą ofiarą zachowawczej polityki energetycznej i klimatycznej). 
Z pewnością ekologiczne nawrócenie, o którym pisze papież Franciszek w encyklice Laudato si', nie nastapi tak łatwo w Polsce. Trudno będzie wyeliminować emisje $\mathrm{CO}_{2}$, związany z tym smog i zanieczyszczenie powietrza oraz zdekarbonizować energetykę. Ale jednocześnie nie można sobie wyobrazić proekologicznej transformacji energetycznej bez szybkiego rozwoju wykorzystania odnawialnych źródeł energii we wszystkich sektorach, a w szczególności w ciepłownictwie i elektroenergetyce (a dopiero potem, z uwagi na ślad węglowy, w transporcie). Jednocześnie szybkiego rozwoju bezemisyjnych OZE i stopniowego wypierania procesów spalania w energetyce nie da się wdrażać bez termicznych, sezonowych magazynów ciepła oraz integracji (tzw. market coupling) rynków ciepła i energii elektrycznej.

Wyzwaniem dla polityki energetycznej ochrony środowiska i klimatycznej jest skorzystanie z zasobów energii słonecznej, wiatrowej i geotermalnej oraz znalezienie takiej ścieżki i tempa zmian struktury energetyki, przy których koszty ekologiczne i ryzyko ekonomiczne będą możliwe najmniejsze, a szanse rozwoju przyszłościowych rozwiązań opartych - zgodnie ze strategią UE - na źródłach całkowicie bezemisyjnych, będą największe.

\section{Bibliografia}

[1] Ministerstwo Energii (2018), Polityka Energetyczna Polski do 2040 roku (PEP 2040), https://www.gov.pl/documents/33372/436746/PEP2040_projekt_v12_201811-23.pdf/ee3374f4-10c3-5ad8-1843-f58dae119936

[2] Michałowska Knap K., Więcka A., Wiśniewski G. (2018), Odnawialne źródła energii - aspekty ekonomiczne i konkurencyjność, w: Prayjazny rožwój Polski. Ludziom Gospodarce - Środowisku, (red.) Adamczewski T., Kassenberg A., Popkiewicz M., Fundacja Instytut na rzecz Ekorozwoju, Warszawa, http://energiaodnowa.pl/ wp-content/uploads/2016/02/Przyjazny-rozw\%C3\%B3j-Polski.-Ludziom-\%E 2\%80\%93-gospodarce- $\% \mathrm{E} 2 \% 80 \% 93-\%$ C5\%9Brodowisku.-.pdf

[3] Wójcik A., Byrka K. (2016), Polacy o zmianach klimatu i polityce energetycznej. Raport z. badania opinii publicznej zleconego w sierpniu 2016 roku przez. WWF Polska w ramach projektu: „Wdrażanie Zrównoważonego Rozwoju na podstawie Odpowiedzialnej Spotecznie Transformacii (WZROST)", LIFE14 GIC/PL/000008, http://energiaodnowa.pl/ wp-content/uploads/2016/10/I-fala-badania-Raport-od-Adriana-i-Katarzyny.pdf 
[4] dma/ wus/ (2018), CBOS: 84 proc. Polakón dostrzega zagrożenia dla środowiska, Nauka w Polsce, http://naukawpolsce.pap.pl/aktualnosci/news\%2C31934\%2 Ccbos-84-proc-polakow-dostrzega-zagrozenia-dla-srodowiska.html

[5] Wiśniewski G., Curkowski A., Pejas B. (2017), Scenariusz średnich kosatón energii elektrycznej do roku 2050 oraz cen w taryfach za energie elektryczna dla wybranych grup odbiorcón do roku 2030, „Energetyka-Społeczeństwo-Polityka” nr 2/(6), DOI 10.4467/24500704ESP.17.004.8860

[6] Instytut Energetyki Odnawialnej (2018), Elektrownia weglowa w Ostrołece vs. fotowoltaika, https://ieo.pl/pl/aktualnosci/1303-elektrownia-weglowa-w-ostrole ce-vs-fotowoltaika-instytut-energetyki-odnawialnej-przeprowadzil-analize-wply wu-wzrostu-cen-i-taryf-energii-elektrycznej-na-oplacalnosc-inwestycji-w-oze

[7] Ruszkowski P. (2018), Opinia publiczna o zagrożeniach środowiska $i$ energetyce konwencjonalnej. Ekespertyza autorska, Warszawa, http://energetyka-collegium.pl/? smd_process_download=1\&download_id=1529

[8] [Wiśniewski G. (2018), Osobliwości polskiej energetyki umyleaja teoriom ekonomicznych noblistów, Blog „Odnawialny”, https://odnawialny.blogspot.com/2018/11/osob liwosci-polskiej-energetyki-umykaja.html

[9] Ruszkowski P. (2010), Oblicza polskiego konserwatyzmu, UKSW, Warszawa

[10] Główny Urząd Statystyczny (2018), Energia ze źródeł odnawialnych w 2017 r., https://stat.gov.pl/obszary-tematyczne/srodowisko-energia/energia/energiaze-zrodel-odnawialnych-w-2017-roku,10,1.html

[11] Parlament Europejski i Rada (2009), Dyrektywa Parlamentu Europejskiego i Rady 2009/28/WE z dnia 23 kwietnia 2009 r. w sprawie promowania stosowania energii ze źródeł odnawialnych zmieniająca i w następstwie uchylająca dyrektywy 2001/77/WE oraz 2003/30/WE, https:/ / eur-lex.europa.eu/legal-content/PL/ $\mathrm{ALL} /$ ?uri=celex$\% 3 \mathrm{~A} 32009 \mathrm{~L} 0028$

[12] Najwyższa Izba Kontroli (2018), Rozwoój sektora odnawialnych źródet energii. Informacja o wynikach kontroli, KGP.430.022.2017, Nr ewid. 171/2017/P/17/020/KGP, https://www.nik.gov.pl/plik/id,18357,vp,20955.pdf

[13] Parlament Europejski i Rada (2018), Dyrektywa Parlamentu Europejskiego i Rady (UE) 2018/2001 z dnia 11 grudnia 2018 r. w sprawie promowania stosowania energii ze źródeł odnawialnych, https://eur-lex.europa.eu/legal-content/ PL/TXT/?uri=CELEX:32018L2001 
[14] European Commission (2016), Commission proposes new rules for consumer centred clean energy transition, https://ec.europa.eu/energy/en/news/commis sion-proposes-new-rules-consumer-centred-clean-energy-transition

[15] European Commission (2016), Commission staff working document: Impact assessment. Accompanying the document. Proposal for a Directive of the European Parliament and of the Council on the promotion of the use of energy from renewable sources (recast) $\{\mathrm{COM}(2016) 767$ final $\},\{\operatorname{SWD}(2016) 419$ final\}, Brussels, SWD(2016) 418 final, https:/ / ec.europa.eu/energy/sites/ener/ files/documents/1_en_impact_assessment_part4_v4_418.pdf

[16] Jacobson M.Z. at al. (2017), 100\% Clean and Renewable Wind, Water, and Sunlight All-Sector Energy Roadmaps for 139 Countries of the World, "Joule" No. 1, http://dx.doi.org/10.1016/j.joule.2017.07.005

[17] Jacobson M.Z., Delucchi M.A., Cameron M.A., Mathiesen B.V. (2018), Matching demand with supply at low cost in 139 countries among 20 world regions with 100\% intermittent wind, water, and sunlight (WWS) for all purposes, "Renewable Energy" Vol. 123 (C), DOI: 10.1016/j.renene.2018.02.009

[18] Urząd Regulacji Energetyki (2018), Energetyka cieplna w licz̧bach - 2017, https:// www.ure.gov.pl/pl/cieplo/energetyka-cieplna-w-1/7662,2017.html

[19] Minister Gospodarki (2010), Krajowy plan dziatan w zakresie energii ze źródet odnawialnych, www.oze.utp.edu.pl/pliki/KPD_RM.pdf

[20] Parlament Europejski i Rada (2012), Dyrektywa Parlamentu Europejskiego i Rady 2012/27/UE z dnia 25 października 2012 r. w sprawie efektywności energetycznej, zmiany dyrektyw 2009/125/WE i 2010/30/UE oraz uchylenia dyrektyw 2004/8/WE i 2006/32/WE, https://eur-lex.europa.eu/legal-content/PL/ALL /?uricelex:32012L0027

[21] Regulski B. (2018), Nie bedzie efek.tymności energetycznej bez efek.tymnego cieplownictwa, Izba Gospodarcza Ciepłownictwo Polskie, https://www.teraz-srodowisko.pl/aktualnosci / nie-bedzie-efektywnosci-energetycznej-bez-efektywnego-cieplownictwa-5834.html

[22] European Union (2107), Medium Combustion Plants Regulations 2017, S.I. No. 595 of 2017, https://www.informea.org/en/legislation/european-union-medi um-combustion-plants-regulations-2017-si-no-595-2017

[23] Komisja Europejska (2016), Komunikat Komisji do Parlamentu Europejskiego, Rady, Europejskiego Komitetu Ekonomiczno-Społecznego i Komitetu Regionów 
Strategia UE w zakresie ogrzewania i chłodzenia $\{$ SWD(2016) 24 final\}, COM (2016) 51 final, https://ec.europa.eu/transparency/regdoc/rep/1/2016/PL/12016-51-PL-F1-1.PDF

[24] Instytut Energetyki Odnawialnej (2018), Systemy cieptownicze wspótpracujace z odnawialnymi źródtami energii $i$ magazynami ciepła, https://ieo.pl/pl/aktualnosci /1282-rozwoj-oze-w-polskim-cieplownictwie-raport-przygotowany-w-ramachprojektu-sdhp2m-sloneczne-systemy-cieplownicze

[25] Parlament Europejski i Rada (2018), Dyrektywa Parlamentu Europejskiego i Rady (UE) 2018/410 z dnia 14 marca 2018 r. zmieniająca dyrektywę 2003/87/WE w celu wzmocnienia efektywnych pod względem kosztów redukcji emisji oraz inwestycji niskoemisyjnych oraz decyzję (UE) 2015/1814, https:/ / eur-lex.europa.eu/legalcontent/PL/TXT/?uri=CELEX\%3A32018L0410

[26] Instytut Energetyki Odnawialnej (2018), Założenia do ustanowienia przez. Narodony Fundusz Ochrony Środowiska i Gospodarki Wodnej programu wsparcia dla cieptownictwa w zakresie budowy, modernizacji i roz̨woju systemów cieptownicąych wspótpracujacych ₹ OZE i magasynami ciepla, Warszawa 